\title{
Female Subjectivity and Confession in Margaret Laurence's A Jest of God
}

\author{
Brenda Beckman-Long
}

\begin{abstract}
A Jest of God est une représentation fictive d'un trouble linguistique, tel que l'illustre la duplicité entre la "voix publique» traditionnelle de Rachel Cameron, ses paroles, et sa "voix privée» dissidente, ses pensées. Margaret Laurence décrit la source de la duplicité de Rachel comme étant le discours maternel. Le texte expose les tentatives de la narratrice de faire la distinction entre ces discours contradictoires. Alors que Rachel situe sa subjectivité dans les discours dominants de Manawaka, elle commence à tenir des discours religieux, des discours différents pour exprimer son expérience. La narration déstabilise la subjectivité féminine inscrite dans le discours dominant et la réinscrit dans un discours féministe.
\end{abstract}

Margaret Laurence's construction of female subjectivity in A Jest of God suggests the underlying feminist ideology that gender roles constrain women in a deathlike existence, unless women interpret their own experience by telling their own life stories. Rachel Cameron's subjectivity is largely determined by the gender roles of the dutiful daughter and unmarried schoolteacher. This characterization is significant because of the relation that exists between narrative and social structures. Laurence exploits this relation. The first paragraph draws attention to Rachel's typicality: she is the "thin giant She behind the desk" (7). The capitalization of the pronoun "She" signals the "generalizing possibilities" of the story and the role of gender in the narrative situation (Lanser 261). The narrator-protagonist reinforces these connections, referring to herself simply as "she" in her fantasies. Rachel is historically representative, for as Jerry Palmer contends, "the 'typical' character . . . is not a representative of a social category, but summarises, in [her] activity, the social processes which constituted the historical moment through which [she] would have lived if [she] had been a real individual." This "typicality" is, then, "a way of being true to history, and narration can be said to be a form of understanding the world" (Palmer 91 ). Both the "typicality" of character and the narrator's confession of selfalienation are effective narrative strategies to persuade the reader of the historical accuracy of Laurence's representation of female experience. ${ }^{i}$

The novel may be characterized as the fictional autobiography of Rachel, the first-person narrator. Helen Buss identifies the novel's "autobiographical impulse" (148), and Nora Foster Stovel states that Rachel "realizes that she must be the author of her own life" (130). Clara Thomas, an early Laurence critic, similarly regards the novel as "a record of a tortured but unremittingly honest journey of self-analysis and self-therapy" $(1972,160)$; she diagnoses Rachel as "neurotic," tracing Rachel's neurosis to her mother's $(1975,78)$. Recent critics, 
such as Rosalie Murphy Baum, agree that neurosis is central to the novel's conflict (154). However, as Barbara Powell points out, the novel cannot be read simply as the discourse of a neurotic or unstable woman, but rather as a narrative that destabilizes female subjectivity by dramatizing an internal linguistic conflict (22). The novel thus reveals a "woman's dilemma: caught within inherited codes" (Howells 95). Laurence exposes female stereotypes: "private selves assigned . . . by liberal humanist discourse"; nevertheless women may "define their various senses of selfhood through their relations with others" (Brydon 203). The novel foregrounds the linguistic conflict that is inherent in female selfrepresentation.

Recognizing the novel's conflict as a linguistic one is necessary to understand the achievement of its ending. It may appear that to escape the codes that confine a woman "within the social decorum of silence" (Howells 95), Rachel must leave the small prairie town. However, even before Rachel boards a bus for Vancouver, her self-understanding must be transformed to imagine life narratives other than those which Manawaka offers. ${ }^{\text {ii }}$ Literary critics comment on the transformative potential of narrative. Peter Easingwood, for example, remarks that Manawaka may be "a difficult and impoverished environment" (258), yet the novel conveys "not a static world, but a world seen to be changing from the inside, beginning with individual experience" (261). The potential for change is linguistic and it involves self-definition (260). This article examines the process of female self-definition and, more specifically, Laurence's use of feminist, autobiographical, and confessional narrative strategies to construct female identity. A Jest of God reveals the self-alienation that Rachel experiences as she is subjected to the female stereotypes of the dominant discourse. At the same time, the novel reveals the transformative potential of alternative discourses and female selfdefinition in particular.

Rachel's voice articulates several discourses, including her mother's, accounting for her apparent instability. Her confession dramatizes an attempt to distinguish between conflicting discourses in a quest for self-understanding and a relatively stable female identity. The confessional process leads Rachel to recognize the dominant discourse of Manawaka, as it is reinforced by her mother's insistence upon propriety, and Rachel locates her subjectivity within that discourse. As she comes into contact with discordant discourses of other characters, including Stacey, Grace, Nick, Hector, and Calla, Rachel is thrown into internal conflict. She is exposed to a plurality of discourses represented by marginalized voices and ecstatic utterances. Eventually, Rachel resists the dominant discourse and constructs a new female identity by engaging with transformative feminist, ethnic, and religious discourses.

From the beginning, Rachel displays a split subjectivity. ${ }^{\text {iii Contem- }}$ porary theorists think split subjectivity is in some respects normative. Chris Weedon explains that consciousness is "the fragmented and contradictory effect of a discursive battle for the subjectivity of the individual" (105); therefore, only the individual who has knowledge of more than one discourse and who recognizes a plurality of meanings can undergo a 
change of identity. In fact, Rachel speaks in two voices: a public voice and a private voice. Her private voice silently criticizes but her public voice maintains a conventional politeness. When Calla, for instance, asks Rachel to attend a service at the Tabernacle, the narrative becomes double-voiced:

\begin{abstract}
"Oh, I'm not worried in the slightest." The lie rises to my mouth before I can prevent it, and then I have to go on. "I'll come along, Calla. Of course I will. I said I would". ...

Why am I trapped into this falseness? (34)
\end{abstract}

Rachel's duplicity-that is, her difficulty in expressing her opinions-is habitual. In another instance, she registers only silent dissent about the school principal's use of corporal punishment. As his subordinate, she believes that she is powerless to challenge the status quo and she submits to his authority:

I want only to go to Willard and tell him to listen, just to listen. I am not neutral -I am not detached -I know it. But neither are you, and you do not know it.

I won't go, though. (31-32)

Willard throws Rachel "off balance" (13), because he articulates a patriarchal discourse; furthermore, Rachel does not speak because she fears that dissent may cost her employment. Instead, Rachel is compelled either to speak in a socially acceptable manner or to remain silent.

Fear for her job, however, only partially accounts for Rachel's compulsion toward conventionality. The politeness with which she speaks originates in a maternal discourse that determines what is socially acceptable: "This pleasant voice, learned by Rachel at her mother's knee and reinforced by the ladies of Manawaka, features repression and rationalization. It is deferential, and is marked by the use of linguistic patterns that question, minimize, judge, and negate" (Powell 23). Powell argues convincingly that the mother-daughter bond is "the source of Rachel's linguistic confusion" (29). The novel's first chapter emphasizes the discursive patterns that Rachel has learned from her mother:

Her smock today is the fawn chintz that looks like the kitchen curtains. Well, poor Calla-it isn't her fault that she has no dress sense. ...

Oh God. I don't mean to be condescending. How can it happen, still, this echo of my mother's voice? (10) 


\section{$14 \cdot$ Tessera}

Later, while criticizing Nick as the milkman's son, Rachel recognizes, "It can't be myself thinking like that. I don't believe that way at all. It's as though I've thought in Mother's voice" (70). At times, Rachel fails to recognize the echoes, but the discursive patterns remain. Rachel's criticism of Grace Doherty, for example, resembles Mrs. Cameron's criticism of Cassie Stewart. Rachel thinks, "How could she? She ought to know better. The ignorance of some people is too much" (31). Similarly her mother says, "I can't fathom the thoughtlessness of some girls. She might consider her mother" (64). The resemblance is both syntactical and lexical. Like her mother, Rachel couches her opinions in language that is marked by negativity: “[Willard's] always very nice to me. I can't claim he isn't. There is no real reason why I should dislike him, none at all" (12). While Rachel claims that Willard is a good principal, the negativity of her language registers doubt. Despite her denial, she questions his authority. Mrs. Cameron's opinions are often registered in the same way:

"I don't want to be a nuisance, Rachel. Goodness knows I've never wanted to stand in your way. That's the last thing in the world I'd ever wish to do, believe me. ...

"Well, dear, of course I'm not blaming you for not having considered it. Why should you?" (201)

Despite her assertion that she is "not blaming," Mrs. Cameron does criticize Rachel.

Rachel internalizes the criticism of the maternal voice. It tells her, "Women shouldn't phone men" (137), or she "must not move closer" to Nick (99); moreover, virginity is a "woman's most precious possession" (96). Laurel Boone describes the effect of Mrs. Cameron's "oblique criticism" and "lifedenying" values upon her daughter: "Rachel lives under this law of spiritless conformity. She subjects every thought and feeling to the voice of her mother, which she carries around inside her, and this voice overrules almost all of her lifeaffirming impulses" (279). The maternal voice is the "martyred voice" of self-alienation (23).

Mrs. Cameron voices the dominant discourse of Manawaka that encodes gender ideologies. The dominant discourse suppresses women because it is a patriarchal discourse that effects female self-censorship: Rachel maintains with "self-effacing politeness" an "assumed powerlessness" (Powell 23). Rachel's thoughts are seldom expressed in her public voice if they conflict with the ideology of the dominant discourse ${ }^{\mathrm{iv}}$. The absence of dissent from her public voice shows that women may be silenced. Rachel's duplicity reflects not only an individual conflict, but also cultural and linguistic ones that are associated with gender ideologies.

The narrative also associates Mrs. Cameron and "God." Throughout the novel, references to "God" frequently precede or follow references to Mrs. Cameron, further emphasizing the authority of the maternal voice. 
For example, in the criticism of Calla cited earlier, Rachel's exclamation, "Oh God," directly precedes her comment about the echo of her mother's voice. Incidental remarks such as this one consistently link the two referents. In fact, it is not "God," but rather the godlike maternal voice, as representative of the dominant discourse, that thwarts Rachel's desires by determining her "proper" place. This metaphorical association is central to the semantic structure of the novel, for as the title suggests, A Jest of God draws attention to issues of power and suppression. The maternal voice tells Rachel that self-expression is a "disgrace" (49), a caveat that accounts for her disparaging references to those who make themselves "fools." The metaphor also sheds light on the significance of the novel's last line: "God's pity on God" (209). Rachel's final wish, "God's grace on fools" (209), now that she is one (188), is the confessor's "plea" for acceptance on behalf of herself and her mother (Spender 120). She pities her mother, whose words by the end are no longer constraining, because Rachel has a new understanding of Mrs. Cameron as a frightened dependent. In her confession, Rachel learns not who God is, but who God is not. Just as she learns to recognize that Nick is "not God" (154), she also learns to recognize that her mother is not God; by implication, neither does the dominant discourse represent the word of God.

Rachel's resistance to the dominant discourse that she inherits from her mother is often registered in a dissenting private voice. In fact, her growing disaffection is symptomatic of a recognition of her split subjectivity. Her dissent is generated by her exposure to discordant discourses that are represented by other characters. The first discordant discourse originates with her sister, for Stacey's resistance becomes Rachel's model:

She's very decisive, is Stacey. She knew right from the start what she wanted most, which was to get as far away from Manawaka as possible. She didn't lose a moment in doing it. (17)

Stacey's discourse of desire raises subjects that are taboo in Manawaka, especially for unmarried women. Stacey's sexual knowledge initiates Rachel. She speaks of men's sexual advances and she coaches Rachel to respond: “Men don't like women to be too serious" (89). Stacey articulates female desire: "I guess it must sound crazy to you, Rachel, but another three weeks and I'd be up the walls-I don't mean because of everything here and that—it's just missing Mac — not only around and to talk to-I mean, in bed" (27). Stacey's discourse reflects none of Mrs. Cameron's propriety, challenging the dominant discourse.

Grace Doherty reinforces Stacey's example. Like Stacey's, Grace's discourse is "self-assured" and she speaks "defiantly" without negative politeness. Grace models a maternal voice that is self-defining, as she resists Willard's claim to authority: 
Her voice is filled with capability. She gains strength from [the child's] presence. This is what happens. I've seen it with my sister. They think they are making a shelter for their children, but actually it is the children who are making a shelter for them. (56)

Both Grace and Stacey articulate an empowering maternal discourse that allows them the authority of female self-definition based on experience. Furthermore, they assume a gender role that sanctions female authority: motherhood. These women transform the maternal voice into a voice of power, not powerlessness.

The discourse of Nick Kazlik is also discordant. Nick's discourse belongs to a marginalized ethnic group, the town's Ukrainian immigrants, and he also resists the dominant discourse that is represented by Mrs. Cameron (Bowering 41). Labeled a "Bohunk" (69), Nick eschews the propriety of a white Anglo-Saxon protestantism: "Don't say that [you are a virgin], Rachel. You don't have to. It's not necessary. Let it be, just as it is. Don't worry-I don't think you're a tramp" (98). Nick assumes that Rachel is sexually experienced and he dismisses Rachel's scruples about lovemaking in a field. Just as Nick's discourse encourages Rachel to drop her sexual inhibition, it also encourages her to drop her verbal inhibition. Rachel thinks that he is "outspoken. More able to speak out. More allowed to- both by your family and by yourself" (94). Although Rachel does not easily overcome propriety, she finds Nick "easy to talk to"; eventually, he recognizes "that polite voice" of hers as "deceptive" (106). Nick's discourse reinforces Stacey's in that it enables Rachel to articulate her desire: "Nick, do you know what I love about you? I love the way your voice sounds, deep but with that scepticism I used to fear and don't fear now, and the way your skin feels, and the hair that grows blackly down to your belly and around your sex" (121). She also articulates observations about herself that she might otherwise deny: "I talk to him, when he is not here, and tell him everything I can think of, everything that has ever happened, and how I feel and for a while it seems to me that I am completely known to him" (144). As an addressee of Rachel's confessions, Nick becomes a vehicle of self-discovery.

At the same time, Rachel makes Nick the subject of daydreams that draw upon conventional romantic discourses to construct fantasies of marriage (Heinemann 53). When Rachel misinterprets Nick, however, he leaves and becomes an absent addressee. The narrative then reinscribes Rachel's voice as an anguished, isolated confessor: "[When] monologists address their inner discourse to one or more mind-haunting interlocutors. . . . All these make-believe communications underscore the pervasive loneliness of the monologist, whose only true interlocutor remains the "Imprisoned Self'" (Cohn 245). When the relationship with Nick ends, Rachel retains "only guarded echoes of his voice" (160).

Another alternative discourse is that of Hector Jonas, the local mortician. If sex is a taboo subject in Manawaka, death is equally taboo: "funeral. A nasty 
word, smacking of mortality. No one in Manawaka ever dies, at least not on this side of the tracks. ... Death is rude, unmannerly, not to be spoken to in the street" (19-20). In contrast to the dominant discourse, Hector speaks frankly about death: it is undeniable because "It happens" (127). His business flourishes because he is an outsider who reads the town well and plays to its overriding concern for propriety. In an almost prophetic discourse, Hector articulates Rachel's memory of her father. Hector confirms that Niall Cameron lived a withdrawn life as an alcoholic, but he informs Rachel that his occupation alone could not account for Niall's behaviour: "I would bet he had the kind of life he wanted most" (131). This insight strikes Rachel as a revelation:

Hector Jonas. . . . Comic prophet, dwarf seer. The life he wanted most. If my father had wanted otherwise, it would have been otherwise. Not necessarily better, but at least different. Did he ever try to alter it? Did I, with mine? (131)

Hector reveals that her father embodies a Manawakan approach to life that is lifeand death-denying in its status quo. Rachel temporarily suspends propriety to accept Hector's "plump well-meaning arm across my shoulders" (133). Hector's discourse exposes the emptiness of Rachel's life as a deathlike existence that is prescribed by the dominant discourse.

The discordant discourse that is most pivotal for Rachel is that of Calla Mackie. Like Stacey and Grace, Calla is "brash" and "strong." She challenges the patriarchal discourse of Willard and the town; she disregards appearances and paints her walls lavender. She subverts the stereotype of the spinster that defines Sapphire Travis. This stereotype, which Rachel fears, discredits unmarried women even if they observe social conventions. Calla nonetheless remains active in the community as a single professional.

Calla's voice is marginalized not only because she is unmarried, but also because she is lesbian. When Calla kisses Rachel, her lesbian desire poses such a threat to Rachel that she does not name it: "The word 'lesbian' does not appear in this novel because the word is not in Rachel's vocabulary" (Relke 36). Calla's words are radical in their expression of both desire and care. When Rachel confides that she may be pregnant, Calla responds:

You could move in here, if you wanted. Or if you wanted to move away entirely, beforehand-well, there isn't any particular reason why I couldn't move, if you wanted someone by you. ... We could manage. As for the baby, well, my Lord, I've looked after many a kid before. (182) 
Diana Relke argues that Calla is a surrogate mother who differs from Mrs. Cameron: "Calla's role as Rachel's surrogate mother is related to her sexual identity. Her love for Rachel makes her more sensitive to Rachel's emotional and psychological immaturity than is Mrs. Cameron, who puts 'appearances' and her own needs before the welfare of her daughter" (41). Like Stacey and Grace, Calla transforms the maternal voice. Calla's words inscribe an alternative subject position for Rachel as a woman who deserves love and respect. In fact, Calla's words enter Rachel's private voice when she comforts herself: "Rachel, hush. Hush, child" (183).

While Calla suppresses her sexuality because lesbian desire is taboo, she does not suppress her sexual energy entirely:

A woman has three ways of dealing with her sexuality in ultraconservative Manawaka: she can marry and pursue a heterosexual lifestyle; she can repress her sexuality and let it turn her into a neurotic, as repression is doing to Rachel; or she can sublimate it in religion-turn her sexual energy into spiritual energy. It is this last alternative which Calla chooses. (Relke 38)

Calla expresses her spiritual energy in a religious discourse that encourages ecstatic utterances. The Tabernacle of the Risen and Reborn poses an alternative to Mrs. Cameron's Scots-Presbyterian church, where religious discourse is subsumed by the prevailing culture text: "If the Reverend MacElfrish should suddenly lose his mind and speak of God with anguish or joy, or out of some need should pray with fierce humility as though God had to be there, Mother would be shocked to the core" (47). Mrs. Cameron believes that religion is "not a subject for discussion." While Rachel's mother makes religious experience yet another taboo, Calla seeks spiritual fulfillment.

Calla's discussion of glossalalia, or "the gift of tongues," introduces Rachel to a religious discourse that transforms her self-understanding. Calla unwittingly diagnoses Rachel's linguistic disorder: "We hold ourselves too tightly these days, that's the trouble. Afraid to let the Spirit speak through us" (33). Calla trusts ecstatic utterances, and Rachel experiences her first ecstatic utterance at the Tabernacle. Initially, Rachel condemns participants who speak in tongues for the "foolery" of making themselves "a public spectacle" (41), but by the end of the meeting she voices her own confusion:

\section{That voice!}

Chattering, crying, ululating, the forbidden transformed cryptically to nonsense, dragged from the crypt, stolen and shouted, the shuddering of it, the fear, the breaking, the release, the grieving -

Not Calla's voice. Mine. Oh my God. Mine. The voice of Rachel. (42-43) 
Rachel diagnoses her linguistic confusion, likening it to a deathlike existence, which some repressed part of her hopes to escape. As Karin Beeler remarks, "This encounter with the 'strange' confusion of religion represents a confrontation with the self; the experience echoes the dismantling of hegemonic and secure structures which Rachel accomplishes through her interface with ... difference" (29). However, this first utterance is nonverbal and unaccompanied by any insight into the cause of her confusion.

The gift of tongues becomes a metaphor for human communication, "not merely verbal communication, but emotional, sexual and spiritual communication" (Relke 35). A series of crises-the departure of Nick, followed by a suspected pregnancy and diagnosis of a uterine tumor-precipitates Rachel's insight that conflicting discourses can cause ruptures between people and within the self. In retrospect, Rachel realizes that she misunderstood Nick despite their sexual intimacy: "We talked sometimes, and I tried to hear what he was saying, but I'm not certain I did hear" (160). She begins to approach her confusion as a linguistic problem, observing the irony "that we should for so long believe it is only the few who speak in tongues" (140). Calla's reference to Saint Paul becomes part of Rachel's new self-understanding:

There are, it may be, so many kinds of voices in the world, and none of them is without signification. Therefore, if I know not the meaning of the voice, I shall be unto him that speaketh a barbarian, and he that speaketh shall be a barbarian unto me (141).

Rachel reverses her opinion of the gift of tongues as an oddity, applying the metaphor to herself. She recognizes that people who do not share the same discourse may appear "alien" to one another.

She uses the metaphor once again in a suicide attempt. In a disjointed, confessional prayer of desperation, she finds that God is also alien to her: "If You have spoken, I am not aware of having heard. If You have a voice, it is not comprehensible to me" (177). As Christian Riegel remarks, "She now reaches out, albeit with little belief, to God as the Other voice in her mind" (Riegel 65). In fact, "God" is a name that she applies not to the transcendent God, but rather to the cultural forces that shape her life story. She makes this distinction only after drawing the metaphor of the gift of tongues. She concludes that the authority of ecstatic utterances is experiential: as the preacher says, "I am going to read ... from The Book of Life" (39). Rachel, too, learns to "read" from "the book of life," as she begins to interpret her experience as the basis of self-understanding. ${ }^{v} \mathrm{Her}$ mother's discourse, which has hitherto defined Rachel's identity, comes into conflict with the discourse of experience. This linguistic conflict is the source of her confusion.

The narrative records two further ecstatic utterances. First, after the diagnosis of a uterine tumor, Rachel utters again in "that other voice, wordless 
and terrible, the voice of some woman mourning for her children" (187). This time, she has some insight into the conflicting discourses that cause her alienation. She thinks of pregnancy as "most wanted" (165), despite her mother's stereotyping of an unmarried mother as a fallen woman (64). By only half-heartedly practicing birth control, Rachel has acted upon her desire to become pregnant. After a negative test, an ecstatic utterance of mourning undermines the authority of the doctor whose propriety reiterates the dominant discourse (Riegel $65)$. His words assume that Rachel would be "sensible" enough to comply with gender ideologies that require chastity of unmarried women; he fails to suspect her resistance. As the crisis unfolds, Rachel assumes the authority of female selfdefinition based on experience. Second, after the tumor's removal, Rachel utters again but this utterance is verbal: "I am the mother now" (191). This utterance appropriates the authority of the maternal voice. Based on the experience of caring for her mother, a dependent though elderly "child" (208), and following the examples of Stacey, Grace and Calla, Rachel transforms the maternal voice. She supplants the maternal voice of propriety to replace it with "the voice of Rachel" by articulating alternative discourses to interpret her experience.

The last chapter records Rachel's attempts to transform her discourse. She announces to her mother that they are moving to Vancouver. She decides to leave behind a deathlike existence in Manawaka. She hopes that by leaving Manawaka, she may enter an environment where a plurality of discourses exists; however, she has already engaged a plurality of discourses in Manawaka. Female subjectivity is not geographically but linguistically determined, as dramatized by Laurence's skillful narrative. In Vancouver, Rachel may be able to engage more fully in a discourse that she shares with Stacey, who is "the only person I could talk to" (174).

The new self-understanding that is inscribed in Rachel's discourse is evidenced in her mother's reaction to the "voice of Rachel" (43), which she finds alien: "Rachel, you're not yourself. You're not talking a bit sensibly, dear. I can hardly follow you" (199). Mrs. Cameron cannot comprehend her daughter's meaning because Rachel resists the dominant discourse. Instead of assuming propriety, her voice echoes "something of Nick's" frankness (202). She asserts Calla's opinion that appearing to be a fool is "the least of [her] worries" (205), and she admits that her fear of Willard is "as unnecessary as my mother's fear of fate" (204). Significantly, she differentiates between her mother and God, stating that Mrs. Cameron's health is "in other hands," those of "God, for all I know" (201202). She also differentiates between herself and her parents by taking responsibility for her own life: "Whatever it was that happened with either of them, their mysteries remain theirs. . . I I have my own" (206). She is "the mother now" (203), for she has constructed a new identity. She becomes an active agent in her own discourse:

Her final paragraph begins tentatively, "I may become, in time, slightly more eccentric all the time" (201), but then moves to the strength of her predictions with each sentence stating "I will." Coupled with this modal auxiliary are the active verbs "push," "pull," "find," "walk," "look," "grow," and "rage," among others. Rachel's patterns of transitivity have shifted, so that in future, she will be the agent of her fate, not just the passive experiencer. (Powell 34) 
She therefore abandons the "powerless, self-effacing strategies of negative politeness and the hedgings and hesitations of her mother's stereotypical women's speech"; instead she is able "to act" and "to do something with words" (Powell 34).

Finally, her discourse transforms a split subjectivity, which results from the conflict between the dominant discourse and alternative discourses of female experience, into a more stable subjectivity. Gone is her duplicity. In addition to alternative discourses of other characters, Rachel draws upon religious discourses to interpret her experience. She employs the metaphor of speaking in tongues. She no longer prays for nothing to happen, but she prays, "Make me to hear joy and gladness, that the bones which Thou hast broken may rejoice" (208). This allusion to the fifty-first Psalm-and the Confessions of Saint Augustine (91)-recalls the generic conventions of confession that metaphorically associate linguistic breakdown with physical brokenness and a quest for healing. Laurence employs confessional and autobiographical forms as narrative strategies for female self-representation. As Leigh Gilmore points out, "women writers frequently describe writing an autobiography as an empowering process through which they reach an understanding, however provisional, of the relationships through which identity is produced" (Gilmore 73). The result of Rachel's adoption of alternative discourses is the destabilization of a female subjectivity that is determined by the dominant discourse.

The confessional quest for self-understanding and the feminist project of female self-definition do not, however, signal an unequivocal achievement of change but rather a potential for change. The indeterminacy of the novel's ending is emphasized by the statement, "I will be different. I will remain the same" (209). This ending implies a dialectical conception of the subject, which Paul Smith sees as a peculiar strength of feminist discourse: "The 'subject,' in the widest catchment of feminist discourse, has been formulated both in terms of its experience as a dominated 'subject' and also as an active and contestatory social agent" (Smith 152). Laurence's narrative exhibits the embedded feminist ideology that resistance to patriarchal discourses is possible: the "interpellation of the 'subject' into oppressed positions is not complete and monolithic" (Smith 152). Rachel is subjected to cultural and linguistic forces that shape her identity, but she is also an agent who is capable of self-definition. While Rachel's identity is transformed, her lack of power is not erased and the dialectical tension is sustained. A Jest of God can be read as a gendered confession that is representative of an historical quest for female self-representation and part of a growing body of women's fictional autobiography. 
Notes

${ }^{i}$ An earlier version of this paper was presented at the Canadian Congress of Social Sciences and Humanities at Dalhousie University, Halifax on May 30, 2003. I am indebted to Raymond Mise, Jeanne Shami, and Kathleen Wall at the University of Regina for reading my drafts.

ii Paul Hjartarson draws the same conclusion about Morag Gunn, who in The Diviners seeks "desperately to escape Manawaka and the life narratives it appears to offer" (52).

iii In his Confessions Augustine writes, "My inner self was a house divided against itself" (122). Among others, Nora Foster Stovel uses the term "divided self" (122). See Coral Ann Howells (95) and Christian Riegel (50) regarding the doublevoiced narrative.

iv Even the town's name "Manawaka" suggests the patriarchy of a place where "Man walks."

$\checkmark$ As Chris Weedon explains, experience is always open to contradictory interpretations: "It is possible to transform the meaning of experience by bringing a different set of assumptions to bear on it." Despite "the provisional nature of meaning," the way in which one interprets her experience nonetheless has "real effects," particularly in terms of its social implications (85-86).

\section{Works Cited}

Augustine, Saint (of Hippo). Confessions. Trans. R. S. Pine-Coffin. London: Penguin, (1961) 1988.

Baum, Rosalie Murphy. "Self-alienation of the Elderly in Margaret Laurence's Fiction." In New Perspectives on Margaret Laurence. Ed. Greta McCormick Coger. Westport: Greenwood, 1996. 153-60.

Beeler, Karin C. "Ethnic Dominance and Difference: the Post-Colonial Condition in Margaret Laurence's The Stone Angel, A Jest of God, and The Diviners." In Cultural Identities in Canadian Literature. Ed. Bénédicte Mauguière. New York: Peter Lang, 1998. 25-37.

Boone, Laurel. "Rachel's Benign Growth." Studies in Canadian Literature 3 (1978): 277-81.

Brydon, Diana. "Silence, Voice and the Mirror: Margaret Laurence and Women." In Crossing the River: Essays in Honour of Margaret Laurence. Ed. Kristjana Gunnars. Winnipeg: Turnstone, 1988. 183-205.

Buss, Helen M. "Margaret Laurence and the Autobiographical Impulse." In Crossing the River: Essays in Honour of Margaret Laurence. Ed. Kristjana Gunnars. Winnipeg: Turnstone, 1988. 147-68.

Cohn, Dorrit. Transparent Minds: Narrative Modes for Presenting Consciousness in Fiction. Princeton: Princeton UP, 1978. 
Easingwood, Peter. "Margaret Laurence, Manawaka and the Edge of the Unknown." World Literature Written in English. 22.2 (1983): 254-63.

Gilmore, Leigh. "Policing Truth: Confession, Gender, and Autobiographical Authority." In Autobiography and Postmodernism. Ed. Leigh Gilmore et. al. Amherst: $\mathrm{U}$ of Massachusetts $\mathrm{P}, 1994$. 54-78.

Heinemann, David. "Ironized Man: A Jest of God and Life Before Man." Canadian Literature. 154 (1997): 52-67.

Hjartarson, Paul. “'Christie's Real Country. Where I Was Born': Story-Telling, Loss and Subjectivity in The Diviners." In Crossing the River: Essays in Honour of Margaret Laurence. Ed. Kristjana Gunnars. Winnipeg: Turnstone, 1988: 43-64. Howells, Coral Ann. "Weaving Fabrications: Women's Narratives in A Jest of God and The Fire-Dwellers." In Critical Approaches to the Fiction of Margaret Laurence. Ed. Colin Nicholson. Vancouver: U of British Columbia P, 1990. 93-106.

Lanser, Susan Sniader. The Narrative Act: Point of View in Prose Fiction. Princeton: Princeton UP, 1981.

Laurence, Margaret. A Jest of God. 1966. Toronto: McClelland and Stewart NCL, 1991.

Palmer, Jerry. Potboilers. New York: Routledge, 1991.

Powell, Barbara. "The Conflicting Inner Voices of Rachel Cameron." Studies in Canadian Literature. 16.1 (1991): 22-35.

Relke, Diana M. A. "Pillar, Speaker, Mother: The Character of Calla in A Jest of God." Studies in Canadian Literature. 13.1 (1988): 34-46.

Riegel, Christian. Writing Grief: Margaret Laurence and the Work of Mourning. Winnipeg: U of Manitoba P, 2003.

Spender, Stephen. "Confessions and Autobiography." In Autobiography: Essays Theoretical and Critical. Ed. James Olney. Princeton: Princeton UP, 1980. 115-122. Smith, Paul. Discerning the Subject. Minneapolis: U of Minnesota P, 1988.

Stovel, Nora Foster. "'Sisters Under Their Skins': A Jest of God and The Fire-Dwellers." In Challenging Territory: The Writing of Margaret Laurence. Ed. Christian Riegel. Edmonton: U of Alberta P, 1997. 119-38.

Thomas, Clara. The Manawaka World of Margaret Laurence. Toronto: McClelland and Stewart, 1975.

"The Novels of Margaret Laurence." Studies in the Novel. 4.2 (1972): 154-64.

Weedon, Chris. Feminist Practices and Poststructuralist Theory. Oxford: Basil Blackwell, 1987. 